'lable 1. Uptake of Sulphate in the Presence of Chloramphenicol ISOMERS

\begin{tabular}{ccccc}
$\begin{array}{c}\text { Chloramphenicol } \\
\text { isomer }\end{array}$ & $\begin{array}{c}\text { Concentration } \\
(\mathrm{g} / 1 .)\end{array}$ & \multicolumn{4}{c}{$\begin{array}{c}\text { \% Inhibition of sulphate uptake } \\
\text { Pea roots }\end{array}$} & $\begin{array}{c}\text { Beet slices } \\
\text { Carrot slices }\end{array}$ \\
D-Threo- & 2 & 92 & 58 & 46 \\
D-Threo- & 1 & 85 & 39 & - \\
D-Threo- & $0 \cdot 5$ & 53 & - & - \\
D-Threo- & $0 \cdot 25$ & 30 & - & 32 \\
L-Threo- & 2 & 84 & 59 & - \\
L-Threo- & 1 & 59 & 45 & - \\
L-Threo- & $0 \cdot 5$ & 37 & - & - \\
L-Threo- & $0 \cdot 25$ & 19 & - &
\end{tabular}

Pea root apices and slices of beet-root and carrot were prepared and shaken in $1 \mathrm{mM} \mathrm{Na}{ }^{36} \mathrm{~S}^{3} \mathrm{SO}_{4}$ at $25^{\circ}$ for $3 \mathrm{~h}$, as previously described (ref. 7 ). The results are averages derived from duplicate flasks.

A sample of L-threo-chloramphenicol (kindly supplied by Dr. R. E. Bowman of Parke, Davis and Co.) had a specific optical rotation of $-19 \cdot 3^{\circ}$ at $20^{\circ}$ and contained less than 1 per cent of the $D$-isomer as determined by a microbiological assay. Table 1 shows that L-threochloramphenicol inhibits the uptake of sulphate by three higher plant tissues; the $\mathrm{L}$-isomer is $65-115$ per cent as effective as the $D$-isomer, depending on the concentration and the tissue. Since the effect of chloramphenicol on salt uptake is largely independent of the configuration around the asymmetric carbon atoms, there is no reason to suppose that this effect necessarily reflects a connexion between the uptake of salt and the synthesis of protein ${ }^{1}$. $\mathrm{L}$-threo-chloramphenicol is not an antibiotic, and these results confirm the view ${ }^{4}$ that the effects of chloramphenicol on plant tissues cannot be explained in terms of effects on the associated micro-organisms. It is suggested that in further studies of this problem all the isomers of chloramphenicol should be used.

Department of Botany,

R. J. ELLIS

University of Oxford.

${ }^{1}$ Sutcliffe, J. F., Nature, 188, 294 (1960).

${ }^{2}$ Brock, T. D., Bact. Rev., 25, 32 (1961).

J Jacoby, B., and Sutcliffe, J. F., J. Exp. Bot., 13, 335 (1962).

- Ellis, R. J., Phytochem. (in the press).

${ }^{5}$ Rendi, R., and Ochoa, S., J. Biol. Chem., 287, 3711k(1962).

'Ronnike, F., Physiol. Plantarum, 11, 421 (1958)

'Ellis, R. J., Joy, K. W., and Sutcliffe, J. F., Phytochem. (in the press).

\section{Disease of Cereals caused by Fusarium nivale}

Hitherto, $F$. nivale (Fr.) Ces. has not been regarded as prevalent in English cereal crops. Bennett ${ }^{1}$ reported that it caused a disease of cereals in the north of England, but he did not regard it as being as serious as $F$. culmorum (W. G. Sm.) Sacc. Moor $\theta^{2}$ has reported it as occasionally occurring in Hampshire. $F$. nivale frequently occurs as a contaminant of oat seeds grown in Scotland ${ }^{3}$ and Northern Ireland4.

During an investigation into Fusarium diseases of cereals now in progress, it was observed in 1961 (Colhoun and Park, unpublished results) that $F$. nivale could be frequently isolated from fairly mature diseased cereal plants in crops in Cheshire and Lancashire. During 1963 a much more extensive survey was undertaken. In spring, 29 samples from winter-sown wheat and barley crops in Yorkshire and Cheshire were examined and from 15 of these $F$. nivale was isolated from diseased plants. The number of infected plants in any crop was usually low. During early July, 68 samples from wheat, barley and oat crops in Bedfordshire, Cambridgeshire, Cheshire, Essex, Suffolk and Yorkshire were examined. In most crops, plants showing marked discoloration of the basal leaf sheaths and stem nodes were found, the culms being sometimes also discoloured. In a crop the number of plants with these symptoms varied from 0 to 80 per cent. In only a small number of crops were no diseased plants found. After surface sterilization, isolations were made from small portions of stem taken from near the base of diseased plants. The great majority of these yielded $F$. nivale although in a rather small number of instances $F$. culmorum or $F$. avenaceum (Fr.) Sacc. was successfully isolated. In a few crops, severe attacks of eye spot (Cercosporella herpotrichoides Fron) or of sharp eye spot (Rhizoctonia solani Kühn) were present; but most frequently infection by Fusarium spp. occurred in the absence of either of these other diseases

In many of the crops examined in July, wheat, barley or oat plants showed a profuse development of perithecia on the lowest leaf sheath These conform to the description of Griphosphaeria nivalis (Schaffnit) Müller and Arx, the perfect stage of $F$. nivale, and single ascospores from them produced typical macro-conidia in culture. The perithecia were most frequently observed on winter-sown wheat. Perithecia were not always associated with the presence of symptoms, and plants of spring-sown wheat from which $F$. nivale was isolated often did not bear perithecia.

In experimental plots sown with inoculated seed in spring, it was observed that perithecia had usually developed by mid-July on the lower leaf sheaths, but later these occurred on leaf sheaths up to the top of the plant. By mid-August perithecia were found on the upper leaf sheaths of control plants which previously had not shown symptoms and had not borne any perithecia.

The evidence obtained convincingly demonstrates that in $1963 \mathrm{~F}$. nivale is by far the commonest species of Fusarium causing disease of cereals in the areas examined. Results obtained from pot experiments clearly show that if seeds heavily contaminated by $F$. nivale are sown they may, in dry soils and under cool conditions, give rise to poor stands through the occurrence of pre-emergence and post-emergence death of seedlings. Seedlings which survive may show the development of well-marked lesions. The extent to which this and other species of Fusarium influence crop yield still remains to be established.

J. Colmoun

G. S. TAYLOR

Department of Cryptogamic Botany, University of Manchester.

Department of Biology, University of Keele.

1 Bennett, F. T., Ann. App. Biol., 20, 272 (1933).

2 Moore, W. C. British Parasitic Fungi (Camb. Univ. Press, 1959).

Noble, M., and Montgomerie, I. G., Trans. Brit. Mycol. Soc., 39,448 (1956).

Res. Exp. Rec. Min. Agric. for the year ended December 31, 1958 (Northern Ireland)

\section{Serological Relationships with Antigens extracted from Green Tissues}

IT is believed that an advance has been made in com. parative plant serology in that specific antigenic proteins have been extracted from green tissues. Gell, Hawkes and Wright ${ }^{1}$ used potato tubers and modified Ouchterlony double diffusion methods ${ }^{2}$ to investigate serological relationships within the genus Solanum. Dorner, Kahn and Wildman ${ }^{3}$ used green tissues when they obtained antisera to proteins extracted from Nicotiana. They investigated the wide distribution of cross-reactions with their antisera throughout the plant kingdom. Kloz, Turkova and Klozova 4 used green tissues in their serological investigation of several species of the Viciaceae. The quantitative method of measuring precipitin used did not allow individual antigen-antibody systems to be distinguished readily.

In the work described here the double diffusion in agargel method ${ }^{2}$ as modified by Gell et al. ${ }^{2}$ was used. The work was centred on two varieties of Marchantia polymorpha L., var. typica and var. aquatica, as described by Burgeff ${ }^{5}$. As large amounts of gametophyte tissue were needed, the bulk of material was gathered from the field. This was supplemented by cultured material of suitable laboratory controls. Cleaned tissue was soaked in 0.7 per cent sodium hydrosulphite in $0.27 \mathrm{M}$ phosphate buffer at $p \mathrm{H} 7.5$ for 30 min. The material was drained and stored in a deep 